\title{
The effect of methanolic extract of Dissotis rotundifolia on cadmium induced testicular damage in whistar rats.
}

\author{
Makanjuola Victor Olufemi ${ }^{1}$, Godam Elvis Tams ${ }^{2}$, Ipinniwa Dolapo A ${ }^{3}$. \\ 1,2,3. Department of Human Anatomy, Faculty of Basic Medical Sciences, College of Health Sciences, Bingham \\ University Karu, Nasarawa State Nigeria.
}

\begin{abstract}
Cadmium is one of the most important toxic heavy metals, reported to have damage the testis of many mammals and Dissotis rotundifolia (Melastomaceae) Triana is known to have many uses in ethnomedicine. This present study was carried out to investigate the effect of Dissotis rotundifolia on the histology, sperm parameters, tissue antioxidant parameters on cadmium damaged testis and also to investigate its possible pro-fertility effect. Thirty (30) adult male Wistar albino rats divided into seven (7) groups were used in this research study. Group A received distilled water only, Group B received $2 \mathrm{mg} / \mathrm{kg}$ b/w of cadmium only. Group $C$ received $2 \mathrm{mg} / \mathrm{kg}$ bw of cadmium and $50 \mathrm{mg} / \mathrm{kg}$ bw of extract, Group D received $2 \mathrm{mg} / \mathrm{kg}$ bw of cadimium and $300 \mathrm{mg} / \mathrm{kg} \mathrm{bw}$ of extract, Group E received $50 \mathrm{mg} / \mathrm{kg}$ bw of exract only, Group F received 300mg/kg bw of extract only, Group G received $2 \mathrm{mg} / \mathrm{kg}$ bw of cadmium and $300 \mathrm{~kg} / \mathrm{mg}$ bw of Vitamin E. Administration was done at 0800 hour daily foor 21days. Adminstration of Dissotis rotundifolia on cadmium induced testicular damage on Wistar rats showed signs of amelorative effect on the histology of testis, sperm parameters while on the normal testis it showed signs of pro-fertility effect, improving the histology of testis, enzyme antioxidant levels and sperm parameters at $50 \mathrm{mg} / \mathrm{kg}$ per $\mathrm{bw}$.
\end{abstract}

KEYWORDS: Cadmium, Dissotis rotundifolia, testis, pro-fertility.

\section{INTRODUCTION}

Exposure of the reproductive system to heavy metals has been reported to be a major risk factor for infertility and there has been an increasing interest in the contribution of occupational and environmental exposures to toxic metals in declining sperm concentration and human male fertility [1].

Cadmium is a heavy metal, which is widely used in industry, affecting human health through occupational and environmental exposure. Cadmium has been reported to damage the testis of many mammals, [2]. Studies have shown that exposure to cadmium causes lipid peroxidation, which is associated with cadmium toxicity in testes and also affects cell proliferation, differentiation, apoptosis and other cellular activities.

Of the many causes of male infertility, oxidative stress (OS) has been identified as one factor that affect fertility status and thus, has been extensively studied in recent years, [3]. Moreover, in men who had decreased sperm counts, motility and increased abnormal sperms, oxidative damage was found to have occurred, [4]. Reports suggest that testis could be protected remarkably from toxic effects of Cd by antioxidant treatment, [5][6]- [7].

The attempt by mankind to use plants and plant products to cure diseases and relieve physical suffering is as old as creation. Plants are extensively used to relieve sexual dysfunction, infertility, heart, lungs, liver disorder and so many other dysfunctions.

Dissotis rotundifolia Triana, a native of tropical West Africa belongs to the Melastomataceae family [8], it comprises of 140 species native to Africa, [9]. The common names include Pink lady (English), Ebafo (Bini), and Awede (Yoruba), [10]. Traditionally, in various parts of tropical Africa, it has various uses. In Nigeria, the plant is used mainly for the treatment of rheumatism and painful swellings, and the leaves decoction is used to relieve stomach ache, diarrhoea, dysentery, cough, stop abortion, conjunctivitis, circulatory problems and veneral diseases, [11]. It is used in East Africa for the treatment of bilharzias, [12], and in Cameroun, the leaves are used for dysentery [10]. This study was undertaken to evaluate the effects of methanolic extract Dissotis rotundifolia Triana on the testes of wistar rats and cadmium induced oxidative damage on rat testis.

Cadmium

\section{MATERIALS AND METHODS}

Cadmium chloride was obtained from the chemistry Department of Bingham University, Karu, Nasarawa State, Nigeria. Before use, cadmium chloride was dissolved in distilled water at a dose of $2 \mathrm{mg} / \mathrm{kg}$ bodyweight and administered to the rats at a single dose intrapretonially. 


\title{
Extraction of Dissotis rotundifolia
}

Dissotis Rotundifolia was obtained in the month of April, 2013 from Itoku market, Abeokuta, Ogun state, Nigeria. It was authenticated by Dr (Mrs) Olorunmaiye P.M; Weed Scientist of Plant Physiology and Crop Production Department, Federal University of Agriculture Abeokuta, Ogun State. The leaves of the plant were removed and air dried under room temperature. The dried leaves were grounded into fine powder and $250 \mathrm{~g}$ of the powder was soaked in 2.0 liters of methanol. The solution was filtered after 24 hours while the filtrate was concentrated to a semi solid form using the rotary evaporator. $20 \mathrm{~g}$ of the concentrate was obtained by meceration method. The stock solution was prepared separately. At high dose, 13.0g of the extract was dissolved into $217 \mathrm{ml}$ of distilled water and at Low dose $2.7 \mathrm{~g}$ of the extract was dissolved into $270 \mathrm{ml}$ of distilled water. Therefore the concentration of the extract given to the Wistar rats at high dose was $300 \mathrm{mg} / \mathrm{kg} \mathrm{b}$. wt and the Low dose was $50 \mathrm{mg} / \mathrm{kg}$ b.wt. The $\mathrm{LD}_{50}$ of the extract was discovered to be $500 \mathrm{mg} / \mathrm{kg}$, [13].

\begin{abstract}
Animals
Male Wistar albino rats with a proven breeding history, weighing between 150 and $200 \mathrm{~g}$ were used for this research. The rats were kept in the animal control room, acclimatized for two weeks before the experiment commenced. The rats were fed on standard diet (Vital Feeds and Grand Cereals Ltd, Kaduna State); water was given (ad libitum ) and maintained under standard conditions. The animal room was well ventilated with a temperature range of $25-27^{\circ} \mathrm{C}$ under day/night $12-12 \mathrm{~h}$ photoperiodicity. The weight of the rats was taken prior to the commencement of treatment and 24hours after the last day of administration before the animal were sacrificed. All the experiments were done in compliance with the guide for the care and use of laboratory animals. The Animals were randomly divided into seven groups $(\mathrm{n}=5)$ as follows:
\end{abstract}

Group A, Rats were administered with distilled water and served as the control group.

Group B, Rats were administered with Cadmium at a dose of $2 \mathrm{mg} / \mathrm{kg}$ body weight.

Group C, Rats were administered with Cadmium at a dose of $2 \mathrm{mg} / \mathrm{kg}$ body weight and treated with Dissotis rotundifolia at a dose of $50 \mathrm{mg} / \mathrm{kg}$ body weight.

Group D, Rats were administered with Cadmium at a dose of $2 \mathrm{mg} / \mathrm{kg}$ body weight and treated with dissotis rotundifolia at a dose of $300 \mathrm{mg} / \mathrm{kg}$ body weight.

Group E, Rats were administerd with Dissotis rotundifolia at a dose of $50 \mathrm{mg} / \mathrm{kg}$ body weight only.

Group F, Rats were administered with Dissotis rotundifolia at a dose of $300 \mathrm{mg} / \mathrm{kg}$ body weight only.

Group G, Rats were administered with Cadmium at a dose of $2 \mathrm{mg} / \mathrm{kg}$ body weight and treated with Vitamin E at a dose of $300 \mathrm{mg} / \mathrm{kg}$ body weight.

Tissue harvesting, morphological examination and gross measurements of the testis:

The animals were sacrificed by cervical dislocation and the testis from each group was excised and weighed on an analytical balance, following abdominal incision, and the right testis was fixed in Bouins fluid for histological analysis while the left testis was homogenized in 5\% sucrose solution for antioxidant assay. Spermatozoa were obtained from the caudal part of the epididymis in normal saline for sperm analysis using Haemocytometer (Neubauer chamber).

\section{Determination of sperm concentration:}

The caudal epididymis was minced in pre-warmed normal saline $\left(37^{\circ} \mathrm{C}\right) .1$ drop of sperm suspension was placed on a glass slide to analyze 200 motile sperm in 4 different fields. The motility of the epididymal sperm was evaluated microscopically within 2 - 4 minute of their isolation from the epididymis, and the data were expressed as percentage motility [14]. Epididymis sperm was obtained by mincing the epididymis in normal saline, and filtering through a nylon mesh $(80-\mu \mathrm{m}$ pore size). The sperm were counted using a hemocytometer. The number of sperm in 5 squares (4 corners and the center) in the center grid of both sides were counted and averaged following the method of Freud and Carol [15]. Sperm morphology was done using 2 drops of Eosin stain, air-dried, and examined under the microscope. The normal sperm cells were counted and the percentage calculated.

\section{Determination of testes enzyme activities:}

Excised testicular tissues were put in Lao style mortar containing $5 \mathrm{ml}$ of $(5 \%)$ sucrose solution and stored at $20^{\circ} \mathrm{C}$ for enzyme analysis. The testicular tissue was transferred to a homogenizer containing cold $5 \mathrm{ml}$ of 5\% sucrose solution. The unbroken cells and cell debris were removed by centrifugation at $3000 \mathrm{rpm}$ for 10 minutes by using centrifuge. Tissue homogenate were collected in $5 \mathrm{ml}$ plain serum bottle for biochemical estimation of testicular levels of: 
The effect of methanolic extract of Dissotis rotundifolia on cadmium induced testicular...

Malondialdehyde (MDA), measured according to the protocol outline by Stocks and Domandy [16].

Superoxide dismutase (SOD), which was assayed according to the method of Mistra and Fridovich [17], using reagent Kit produced by Randox Laboratories Ltd.

Glutathione peroxidase activity which was determined by the method of Paglia and Velentine [18] using the reagent kit made by Randox Laboratories Ltd; Ardmore, Diamond Road, Crumlin Co. Antrim, U.K, BT294QY.

\section{Testicular histology:}

The histology of the testis was done by modification of the method described by Akpantah et al., 2003[19]. The organs were cut in slices of about $0.5 \mathrm{~cm}$ thick transversely and fixed in Bouins fluid for a day after which it was transferred to $70 \%$ alcohol for dehydration. The tissues were passed through $90 \%$ and absolute alcohol and xylene for different durations before they were transferred into two changes of molten paraffin wax for 1 hour each in an oven at $65{ }^{\circ} \mathrm{C}$ for infiltration. They were subsequently embedded and serial sections cut using rotary microtome at six microns $(6 \mu \mathrm{m})$. The tissues were transferred onto albumenized slides and allowed to dry on hot plates for 2 minutes. The slides were dewaxed with xylene and passed through absolute alcohol ( 2 changes); $70 \%$ alcohol, 50\% alcohol and then to water for 5 minutes. The slides were then stained with Haematoxylin and Eosin. The slides were mounted in DPX (Diselene Pthalate xyene). Photomicrographs were taken using $\times 100$ objectives for each group.

\section{Statistical analysis:}

All the data were statistically evaluated using the student's test with SPSS 17.0 software (SPSS Inc, Chicago, USA) and the data were presented as Means \pm Standard Error of Mean (SEM). Differences were considered to be of statistically significance at the probability of less than $0.05(\mathrm{P}<0.05)$.

\section{Results:}

Body Weight Changes:

TABLE 1.0: Body weight changes of wistar rats administered with Dissotis Rotundifolia and Cadmium before and after experiment

\begin{tabular}{|c|c|c|}
\hline GROUPS & INITIAL WEIGHT(g) & FINAL WEIGHT(g) \\
\hline A (Control) & $163.3 \pm 8.82$ & $186.7^{\mathbf{b}} \pm 8.82$ \\
\hline B (Cadmium Only) & $176.0 \pm 8.12$ & $154.0^{\mathrm{a}} \pm 2.45$ \\
\hline $\mathrm{C}$ (Cadmium + Low dose $)$ & $162.0 \pm 3.74$ & $152.0^{\mathrm{a}} \pm 3.74$ \\
\hline $\mathrm{D}$ (Cadmium + High dose $)$ & $160.0 \pm 3.16$ & $150.0^{\mathrm{a}} \pm 3.16$ \\
\hline E (Low dose only) & $155.0 \pm 2.89$ & $167.5^{\mathrm{a}} \pm 2.50$ \\
\hline F (High dose only) & $180.0 \pm 9.13$ & $170.0^{\mathrm{a}} \pm 7.07$ \\
\hline $\mathrm{G}$ (Cadmium + Vit. E) & $157.0^{\mathbf{b}} \pm 4.79$ & $167.5^{\mathrm{ab}} \pm 4.79$ \\
\hline
\end{tabular}

The result above showed that the group B (Cadmium only) caused a decrease in body weights when comparing the initial to the final body weight and the final body weight was significantly different at $(\mathrm{P}<0.05)$ from control (group A). The cadmium + extract groups showed a decrease in weight during the experiment and the finial body weight was significantly different $(\mathrm{P}<0.05)$ from the control group. The leaf extract at low dose (Group E) showed an increase in body weights, while at high dose (Group F) it showed a decrease in body weights during the experiment. The weight of low dose and high dose of extract only (groups E and F) were significantly different $(\mathrm{P}<0.05)$ from the control (group $\mathrm{A}$ ). Group $\mathrm{G}$ treated with Vitamin $\mathrm{E}$ showed a significant increase in body weight when compared to the control and cadmium only group. 


\section{Testicular Weights:}

TABLE 2.0: Effect of methanolic extracts of Dissotis rotundifolia Leaves and Cadmium on the testicular weight of wistar rats.

\begin{tabular}{lc}
\hline GROUP & TESTICULAR WEIGHT(g) \\
\hline A (Control) & $1.42 \pm 0.18$ \\
B (Cadmium only) & $1.08 \pm 0.24$ \\
C (Cadmium + Low dose) & $0.61^{\mathbf{a b}^{\mathbf{b}}} \pm 0.05$ \\
D (Cadmium + High dose) & $0.77^{\mathbf{a}} \pm 0.03$ \\
E (Low dose only) & $1.52 \pm 0.16$ \\
F (High dose only) & $1.37 \pm 0.11$ \\
G (Cadmium + Vit. E) & $0.70^{\mathbf{a b}_{ \pm}} \pm 0.09$
\end{tabular}

Values were expressed as Mean \pm SEM in grams; ${ }^{a}$ Mean significantly different from control (group A) at P

$<0.05 ;{ }^{\mathbf{b}}$ Mean significantly different from cadmium (group B) at $\mathrm{P}<0.05$ (ANOVA).

Result above showed that there was a significant decrease in the testicular weight of rat in group administered with Cadmium only (Group B), when compared with the control $(\mathrm{P}<0.05)$. The group administered with cadmium and extract showed a sigmificant decrease at $(\mathrm{P}<0.05)$ from group $\mathrm{A}$. The group administered with methanolic extract only caused an increase but was not significantly different from control group $(\mathrm{P}<0.05)$. Group G $($ Cadmium + Vit. E) showed a decrease, significantly different $(\mathrm{P}<0.05)$ from the control (group A).

Effect of Treatment on the Testicular Enzymatic Oxidative Stress and Lipid Peroxidation Biomarkers

Table 3.0: Effect of methanolic extracts of Dissotis rotundifolia Triana and Cadmium on SOD, GPx , MDA levels.

\begin{tabular}{lccl}
\hline GROUP & SOD(U/ML) & GPx $(\mathrm{U} / \mathrm{L})$ & MDA(UMOL/L) \\
\hline A (Control) & $421.0^{\mathbf{b}} \pm 6.00$ & $3969.0^{\mathbf{b}} \pm 124.00$ & $25.0^{\mathbf{b}} \pm 1.00$ \\
B (Cadmium only) & $382.5^{\mathbf{a}} \pm 6.50$ & $3024.0^{\mathbf{a}} \pm 78.00$ & $36.0^{\mathbf{a}^{\mathbf{a}} \pm 1.00}$ \\
C (Cadmium + Low dose) & $308.5^{\mathbf{a}^{\mathbf{b}} \pm 6.50}$ & $3876.5^{\mathbf{b}} \pm 70.50$ & $33.0^{\mathbf{a}} \pm 1.00$ \\
D (Cadmium + High dose) & $252.5^{\mathbf{a b}^{\mathbf{b}} \pm 7.50}$ & $2820.0^{\mathbf{a b}^{\mathbf{b}} \pm 25.00}$ & $35.0^{\mathbf{a}} \pm 1.00$ \\
E (Low dose only) & $366.5^{\mathbf{a}} \pm 6.00$ & $3685.0^{\mathbf{a}} \pm 37.00$ & $26.5 \pm 0.50$ \\
F (High dose only) & $415.0 \pm 5.00$ & $3583.5^{\mathbf{a}} \pm 21.50$ & $28.0 \pm 1.00$ \\
G (Cadmium + Vit. E) & $410.0^{\mathbf{b}} \pm 8.00$ & $3626.0^{\mathbf{a}} \pm 34.00$ & $26.0^{\mathbf{b}} \pm 1.00$
\end{tabular}

Values were expressed as Mean \pm SEM; ${ }^{\mathbf{a}}$ Mean significantly different from control (group A) at $\mathrm{P}<0.05 ;{ }^{\mathbf{b}}$

Mean significantly different from cadmium (group B) at $\mathrm{P}<0.05$ (ANOVA). 
The effect of methanolic extract of Dissotis rotundifolia on cadmium induced testicular...

\section{Superoxide dismutase:}

The result above showed that rats administrated with cadmium only caused decrease that is significantly different $(\mathrm{P}<0.05)$ from the control (group A). Co- administration of Cadmium and methanolic extract of $D$. rotundifolia caused a decrease that is also significantly different $(\mathrm{P}<0.05)$ from the control group. Group E caused a decrease which is significantly different $(\mathrm{P}<0.05)$ from the control group and Group F showed an increase but it was not significantly different $(\mathrm{P}<0.05)$ from the control. The group administered with Cadmium+ Vitamin E showed an increase but not significantly different $(\mathrm{P}<0.05)$ from the control group.

\section{Glutathione peroxidase:}

The result above showed that (group G) administered with Cadmium+ Vitamin E caused an increase significantly different $(\mathrm{P}<0.05)$ from the control (group A). Group B caused a decrease significantly different from $(\mathrm{P}<0.05)$ control group. The group administered with Cadmium+ high dose of extract caused a decrease significantly different $(\mathrm{P}<0.05)$ from the control group and group administered with Cadmium + low dose showed an increase in Gpx level but not significantly different $(\mathrm{P}<0.05)$ from the control. The group administered with the extract only was significantly different $(\mathrm{P}<0.05)$ from the control group and at $50 \mathrm{mg} / \mathrm{kg}$ b.wt (Group E) of extract, an increase in Gpx level was seen compared to Group F.

\section{Lipid peroxidation biomarker (Malondialdehyde):}

The result obtained indicate that groups administered with Cadmium caused an increase that is significantly different $(\mathrm{P}<0.05)$ from the control group. The groups administered with the methanolic extract showed a slight increase but not significantly different $(\mathrm{P}<0.05)$ from the control group.

\section{Sperm Parameters}

\section{Sperm count}

Table 4.0: Effect of methanolic extracts of Dissotis rotundifolia Triana and Cadmium on Sperm Count $\left(\times 10^{6} / \mathrm{ml}\right)$.

GROUP $\quad$ SPERM COUNT $\left(\times 10^{6} / \mathrm{ml}\right)$
A (Control)
$89.5^{\mathbf{b}} \pm 0.35$
B (Cadmium only)
$35.5^{\mathrm{a}} \pm 0.50$
$\mathrm{C}($ Cadmium + Low dose $)$
$30.0^{\mathrm{a}} \pm 0.20$
D (Cadmium + High dose $)$
$45.5^{\mathrm{a}} \pm 0.25$
E (Low dose only)
$53.5^{\mathrm{a}} \pm 1.05$
F (High dose only)
$79.0 \pm 0.50$
$\mathrm{G}(\mathrm{Cadmium}+$ Vit. E)
$68.0^{\mathrm{a}} \pm 0.40$

Values were expressed as Mean \pm SEM; ${ }^{\mathbf{a}}$ Mean significantly different from control (group A) at $\mathrm{P}<0.05 ;^{\mathbf{b}}$ Mean significantly different from cadmium only (group B) at $\mathrm{P}<0.05$ (ANOVA). 
Sperm motility and morphology

Table 5.0: Effect of methanolic extracts of Dissotis rotundifolia Leaves and Cadmium on Sperm Motility and Sperm Morphology.

\begin{tabular}{|c|c|c|}
\hline GROUP & SPERM MOTILITY (\%) & $\begin{array}{l}\text { SPERM MORPHOLOGY } \\
(\% \text { ABNORMALITY })\end{array}$ \\
\hline A (Control) & $75.0^{\mathrm{b}} \pm 5.00$ & $5.5^{b} \pm 0.50$ \\
\hline B (Cadmium only) & $25.0^{\mathrm{a}} \pm 5.00$ & $9.5^{\mathrm{a}} \pm 0.50$ \\
\hline $\mathrm{C}($ Cadmium + Low dose $)$ & $20.0^{\mathrm{a}} \pm 0.00$ & $7.5 \pm 0.50$ \\
\hline D (Cadmium + High dose $)$ & $25.0^{\mathrm{a}} \pm 5.00$ & $7.0 \pm 2.00$ \\
\hline E (Low dose only) & $50.0^{\mathrm{a}} \pm 10.00$ & $5.5 \pm 0.50$ \\
\hline F (High dose only) & $55.0 \pm 5.00$ & $10.5^{\mathrm{a}} \pm 1.50$ \\
\hline G (Cadmium + Vit. E) & $30.0^{\mathrm{a}} \pm 10.00$ & $5.5^{\mathrm{b}} \pm 0.50$ \\
\hline
\end{tabular}

Microscopic findings of the effects of methanolic extract of Dissotis rotundofolia on the histology of the Testes of normal and extract treated Whistar rats.

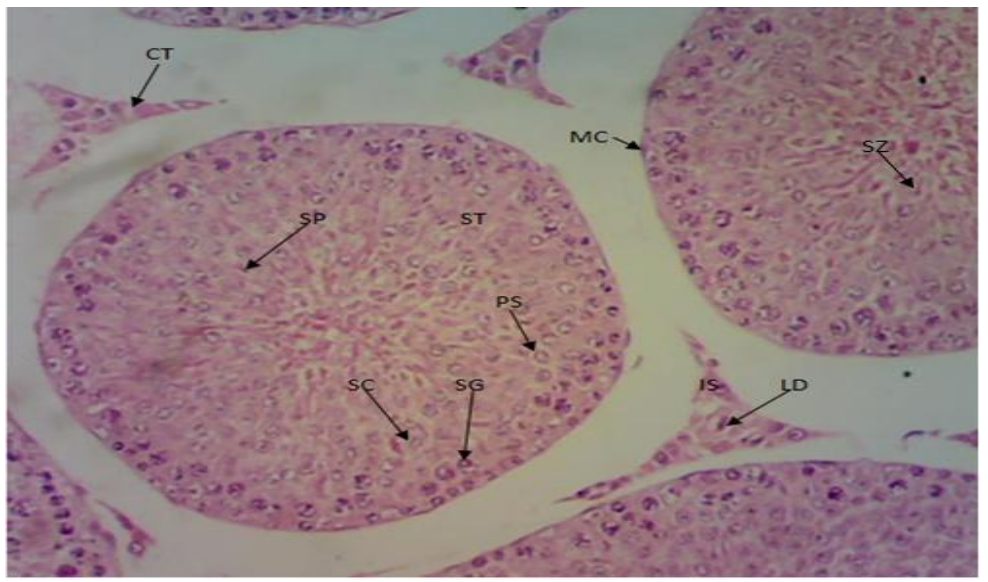

Plate I: Photomicrograph of the testis of Wistar rat from group A (control) is showing normal spermatogenic activities of testis. It showed a normal circular and well arranged ST-Seminiferous tubule with different stages of spermatogenic cells: SG- Spermatogonia, PS- Primary Spermatocyte, SP- Spermatid and SZ-Spermatozoa. Also present are SC- Sertoli cells and the MC- Myoid cells which adhere to the basal lamina. It also showed clumps of interstitial LD-Leydig cells in the IS-Interstitial space, surround by connective tissues. H\&E stain $\times$ 100. 


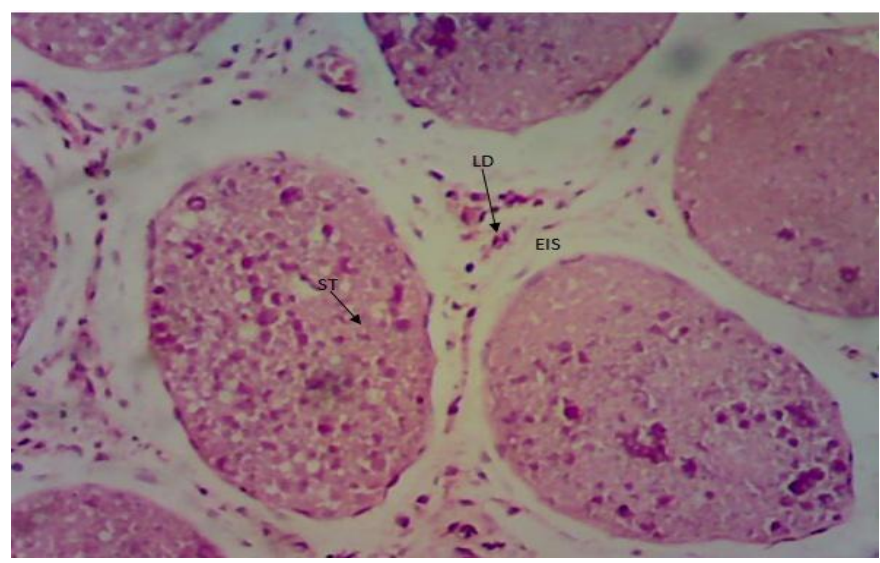

Plate 2: Photomicrograph of the testis of Wistar rat from group B (Cadmium only) is showing total necrotic change in the seminiferous tubules with severely disorganized germinal epithelium. It showed absence of clearly defined basement membrane. It showed EIS-Exaggerated interstitial space with atrophied LD- Leydig cells. H\&E stain $\times 100$.

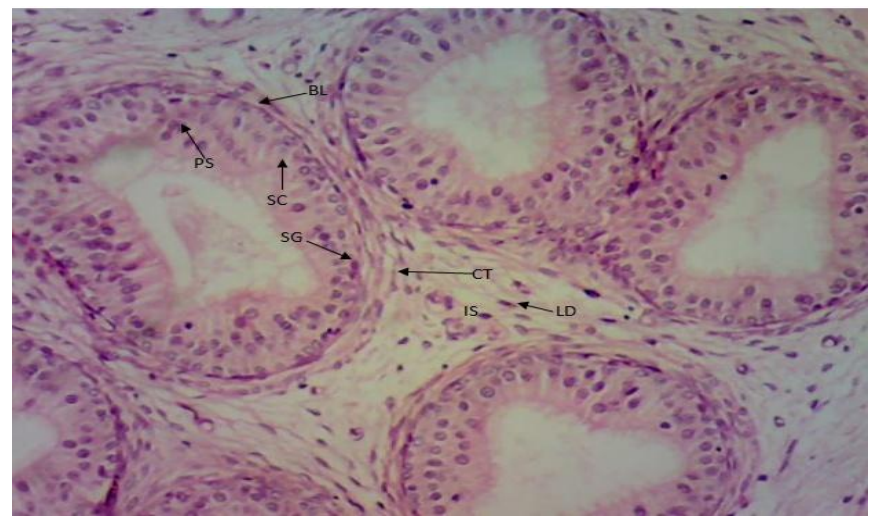

Plate 3: Photomicrograph of the testis of Group C (Cadmium + Low dose of extract) is showing regenerative seminiferous tubules with increasing spermatogenic activities: SG- Spermatogonia, PS- Primary spermatocyte. Also present are regenerating SC-Sertoli cells perpendicular to the BL- Basal lamina. Few regenerative LDLeydig cells in the IS- Interstitial space were observed with few CT-Connective tissues. H\&E stain $\times 100$.

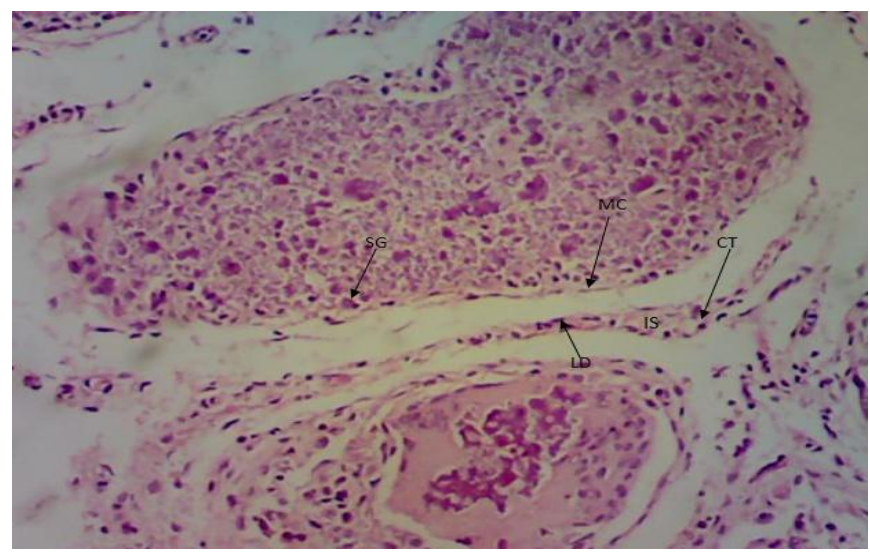

Plate 4: Photomicrograph of the testis of Wistar rat from group D (Cadmium + High dose of extract) is showing necrotic changes with few regenerative spermatogenic activities: SG- Spermatogonia. It showed a mild regenerative myoid cells with increased IS-Interstitial spaces and few LD-Leydig cells, surrounded by a CTConnective tissue. H\&E stain $\times \mathbf{1 0 0}$. 


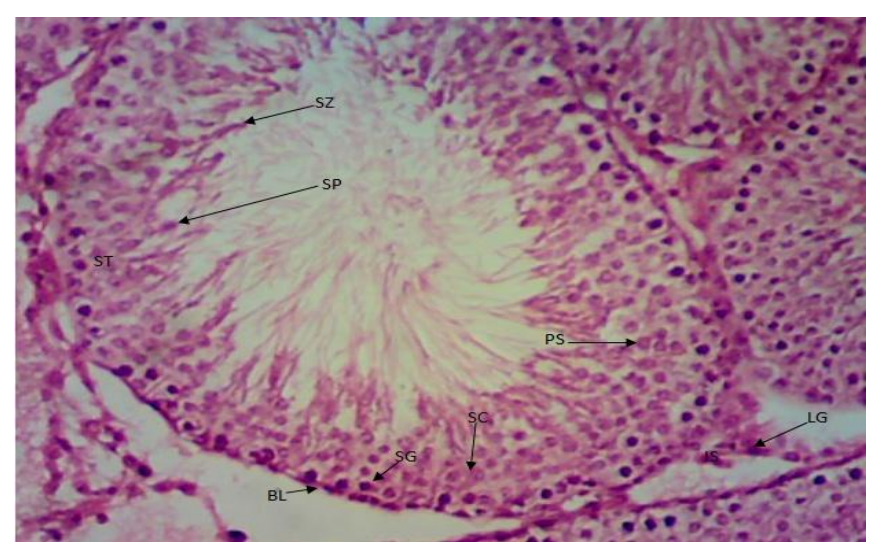

Plate 5: Photomicrograph of the testis Wistar rat of the Low dose only (Group E) is showing a normal STSeminiferous tubules with increasing spermatogenic activities: SG- Spermatogonia, PS- Primary spermatocyte, SP- Spermatid and SZ- Spermatozoa. It showed normal SC- Sertoli cells perpendicular to the BL- Basal lamina. Also present are clumps of LD-Leydig cells in the IS- Interstitial space surround by Connective tissues. H\&E stain $\times 100$.



Plate 6: Photomicrograph of the testis of wistar rat of Group F (HIGH DOSE ONLY) is showing hypertrophy of the ST- Seminiferous tubules and reduced spermatogenic activities. It also showed hypertrophy of the SC Sertoli cells and depleting germinal epithelium, EL-Empty lumen. Also present are EIS- Exaggerated spaces with few LD- Leydig cells. H\&E stain $\times \mathbf{1 0 0}$.

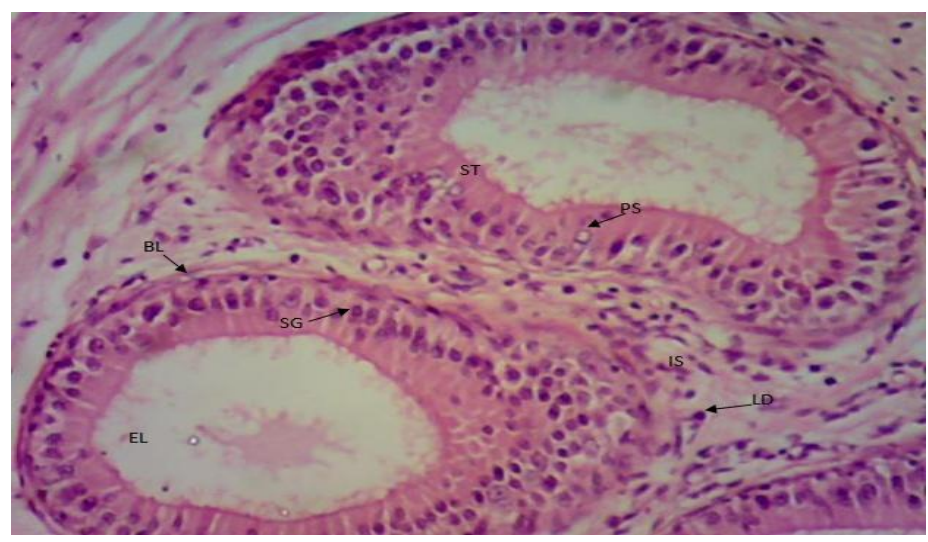

Plate 7: Photomicrograph of the testis of Group G (Cadmium+ Vitamin E) is showing a mild regenerative STSeminiferous tubules with little spermatogenic activities; SG- Spermatogonia, PS- Primary spermatocytes with EL- Empty lumen present. Also present are few recovery of the LD- Leydig cells in the IS- Interstitial space. H\&E stain $\times 100$. 


\section{DISCUSSION}

The present study investigated the effect of extract (Dissotis rotundifolia) on cadmium induced testicular damage in wistar rats based on the testicular weight, histology, sperm parameters and antioxidant parameters. The testicular weight of treatment (cadmium + extract) groups (Table 2.0) decreased significantly as compared to the control due to the degenerative property of the cadmium affecting the testis. The histology of treatment (cadmium + extract) groups (Fig $3 \& 4$ ) showed necrotic changes in the semiferous tubuleswith mild regeneration in spermatogenic activities, basal cells and connective tissues.

The SOD and GPx level of Cadmium + High dose of extract (Group D) decreased significantly (Table 3.0 ) but at $50 \mathrm{mg} / \mathrm{kg}$ bw of extract (Group C) showed a slight significant increase. The decrease in the antioxidant enzymes in Group D was due to the enhanced production of ROS as mention above [20]. MDA level also increased significantly (Table 3.0) compared to the control (group A) due to Lipid peroxidation that occurred in the cell membrane that leads to cell damage and oxidative injury to DNA and protein [21].

The sperm count and motility decrease significantly (Table 4.0 \& 5.0) from the control (Group A). This is due to the adverse effect of the cadmium on spermatogenesis [22]. The sperm abnormalities increased but not significant to the control group. Therefore from the present study, the extract (Dissotis rotundifolia) was shown to have ameliorative effect on cadmium induced testicular damage and can be more protective if administered for a longer period of time.

The present study also demonstrated the effect of methanolic extract (Dissotis rotundifolia) on the normal testis of wistar rats based on the body weight, testicular weight, histological, histochemical and sperm activities of the testis. The body weight of wistar rats administered with extract only showed a significant increase (Table 1.0) when comparing the initial to the final weights. The testicular weight showed an increase at $50 \mathrm{mg} / \mathrm{kg}$ b.wt (Group E) of extract but not significantly different (Table 2.0) from the control (group A) and extract at $300 \mathrm{mg} / \mathrm{kg}$ b.wt (Group F) showed a slight decrease. The Dissotis rotundifolia extract showed a significant increase in the level of the antioxidant defense system, SOD and Gpx (Table 3.0) corresponding with studies mention above [23]. The MDA Level increased slight but no significantly different from the control (group A).

The effect of the extract (Dissotis rotundifolia) on the histology of the extract revealed apparently normal seminiferous tubules and presence of leydig cells in the interstitial spaces just similar to the control (Fig 1 : group A). At $50 \mathrm{mg} / \mathrm{kg}$ b.wt of methanolic extract, (Fig 5: group E) increased activities of the spermatogenic cells were observed. The sperm count (Table 4.0) increased but not significantly different from the control group. The percentage sperm abnormalities were observed to increase in the (Group F) administered wit $300 \mathrm{mg} / \mathrm{kg}$ b.wt of extract suggesting the toxicity of the extract at this dose. Therefore from the present study methanolic extract (Dissotis rotundifolia) can improved the activities of the testis more at $50 \mathrm{mg} / \mathrm{kg} \mathrm{b}$.wt of methanolic extract.

\section{Conclusion}

Administration of Dissotis rotundifolia to cadmium induced testicular damage of Wistar rats showed signs of ameliorative effect on the histological, antioxidant status, and sperm activities of the testis at $50 \mathrm{mg} / \mathrm{kg}$ b.wt. On the other hand, administration of Dissotis rotundifolia on the normal testis was found to show signs of pro-fertility effect and a little sign of improvement on the histology of testis and sperm parameters at $50 \mathrm{mg} / \mathrm{kg}$ per body weight and also found to improve the enzyme antioxidant levels.

\section{Recommendation}

Dissotis rotundifolia Triana has shown signs of ameliorative effect on the damaged testis, therefore further work can be done with longer period of administration at $50 \mathrm{mg} / \mathrm{kg}$ body weight or less, for the protective role on the testis to be effectively seen. It is also advised that the continual usage of Dissotis rotundifolia Triana should be with caution particularly above the recommended dose. 


\section{REFRENECES}

[1]. O. Akinloye, A.O Arowojolu, and O.B, Shittu. Cadmium toxicity: a possible cause of male infertility in Nigeria. Reproductive Biology Anctor J.I, 2006. 6(4): 17-30.

[2]. J. Parizek, and Z. Zahor. Effect of cadmium salts on testicular tissue: London. Nature, 1996 177: 1036-1037.

[3]. I.D Sharlip, J.P Jarow, A.M. Belker, A.M. Best practice policies for male infertility. Fertil Steril, 2002. 77: 873-882

[4]. M. Ebesunun, B.A Solademi, O.B Shittu, J.I Anetor, J.A. Onuegbu, J.M Olisekodiaka. Plasma and semen ascorbic levels in spermatogenesis. West Afr J Med, 2004. 23(4): 290-293.

[5]. J. Yiin, L. Chern, Y. Sheu and H. Lin. Cadmium induced lipid peroxidation in rat testes and protection by selenium. Biometerials, 1999. 12: 353-359.

[6]. R. Gupta, J. Kim, C. Gomes, S. Oh, J. Park, B. Im, Y. Seong, Ahn, S., B. Kwon, J. Soh, (2004a). Effect of ssascorbic acid supplementation on testicular steroidogenesis and germ cell death in cadmiumtreated male rats. Molecular Cellular Endocrinology, 2004a. 221: 57-66.

[7]. R. Gupta, E. Gupta, K. Dhakal, R. Thakur, R. Ahnn, J. (2004b). Vitamin C and vitamin E protect the rat testes from cadmiuminduced reactive oxygen species. Molecular Cells, 2004b. 17: 132-139.

[8]. W.L. Wagner, D.R, D.R. Herbst, and S.H. Sohmer, (1990). Manual of flowering plants of Hawaii: University of Hawaii Press, Bishop Museum, Honolulu, 1992. 5(1): 205-210.

[9]. H.A. Loigie, 1994. Spermatophyta: Descriptive flora of Puerto Rico and Adjacent islands. 1-3. [10] [10] A. Gill and S.Akinmumi. (1992). Study of plant used in ethnomedicine. West Afr J Med 26(4): 50-54.

[10]. E. Noumi, and A. Yomi . Medicinal plants used in intestinal diseases. Fitoterapia, 2001. 12(3): 246-254

[11]. J.C. Kokwaro, (1996). Medicinal plants of East Africa. General Printers. Nairobi; 1996. 22(4): 198.

[12]. A.A. Adefemi. 1988. Evaluation of thr toxicity potential of Dissotis rotundifolia. West African Journal of pharmacy and drugs, 1988. $8 ; 4.48$

[13]. R.E, Morrisey, B.A. Schwctz, C. James, D.R. Monica, J.L. Teague, R.W. Moris. Evaluation of rodent sperm, vagina cytology and Reproductive organ weight from National Toxicology Programme-13 weeks studies. Fundam Appl Toxico, 1988. 11: $343-58$.

[14]. M. Freund, B. Carol. Factors affecting haemocytometer count of sperm concentration in human semen. J Reprod Fertil,1964. 8: $149-152$.

[15]. J. Stocks, T.L. Domandy, The antioxidation of human red cell lipids induced by hydrogen peroxide. Br. J. Haemat. 20, 197. 951111.

[16]. H.P, Misra, and I Fridovich, I. Method of determination of superoxide dismutase (SOD). J. Biol. Chem., 1972. $247: 3170$.

[17]. D.E. Paglia, and W.N. Valentine. Studies on the quantitative and qualitative characterization of erythrocyte glutathione peroxidas. J. Lab. Clin. Med. 1967. 70: 158-169e.

[18]. A.O. Akpantah, A.A Oremosu, M.O. Ajala, C.C. Noronha, and A. Okanlawon. The effect of crude extract of Garcinia kola seed on the histology hormonal milieu of male Sprague dawley rats reproductive organs. Nig J Health Biomed Sci, 2003. 2(4): 40-46.

[19]. S.J Stohs, D. Baghi, E. Hassoun and M.M Begchi. Oxidative mechanisms in the toxicity of chromium and cadmium ions. J Envron Patho Toxicol Onco, 2000. 19(1): 201-213.

[20]. T. Lane, W. Saito, A. Mark, N. George, I. Pickering, C. Roger, M. Morrel and M.M. Francois, 2005. Cadmium enzyme from a marine diatom. Nature,. 435; 42

[21]. U.R, Acharya, and M. Mishra (2003). Lead acetate induced cytotoxicity in Male germinal cells of swiss rats. Industrial Health 2003. 41: 291-294

[22]. J. Byung, and Pal Yu. Cellular defenses against damage from reactive oxygen species. J Physiological Reviews, 1994. 7: 134163 